\title{
Exploring Managers' Feelings about Employee Involvement in Change
}

\author{
Stavros Georgiades ${ }^{1}$, Walter R. Nord ${ }^{2} \&$ Georgio Georgiades $^{3}$ \\ ${ }^{1}$ Business School, Frederick University, Limassol, Cyprus \\ ${ }^{2}$ College of Business, University of South Florida, Florida, USA \\ ${ }^{3}$ Hult International Business School, London, UK \\ Correspondence: Stavros Georgiades, Business School, Frederick University, 18 Mariou Agathagelou Str, Agios \\ Georgios Havouzas, Limassol 3080, Cyprus. Tel: 357-25-730975. E-mail: bus.gs@frederick.ac.cy
}

Received: October 27, 2013

Accepted: December 10, 2013

Online Published: December 12, 2013

doi:10.5430/bmr.v2n4p71

URL: http://dx.doi.org/10.5430/bmr.v2n4p71

\begin{abstract}
The purpose of this paper is to increase our understanding of organization change and employee involvement by closing a gap in the current literature. Specifically, we believe that scholars have failed to adequately study how managers view employee involvement. This lacuna is noteworthy given an apparent consensus about the value of employee involvement to successfully introduce change. The study revealed overlap between how academics approached the matter and how managers do. However, study of the managers' thoughts uncovered some interesting nuances about how they manage the process. These nuances point to directions for research that could sharpen our understanding about the change process. The results can be an important step for integrating existing knowledge about employee involvement in change and managers' needs to make it happen.
\end{abstract}

Keywords: Employee involvement implementation, Communication, Empowerment, Motivation

\section{Introduction}

\subsection{Introduce the Problem}

The purpose of this paper is to increase our understanding of organization change and employee involvement by closing a gap in the current literature. Specifically, we believe that scholars have failed to adequately study how managers view employee involvement. This lacuna is noteworthy given an apparent consensus about the value of employee involvement to successfully introduce change.

There is consensus among academics that to introduce change successfully, managers often need to gain the support of employees (Delaney \& Sockell, 1990; Cobb et al., 1995; Tesluk et al., 1999; Morgan \& Zeffane, 2003). To do so, they are advised to use practices that empower employees via both the provision of employee development (Block, 1987; Conger \& Kanungo, 1988; Rusaw, 2000; Detert \& Burris, 2007; Tangirala \& Ramanujam, 2008) and operational freedom (Bandura, 1986; Conger, 1986; Nord et al., 1993; Tierney, 1999; Zhang \& Bartol, 2010). Also they should use several motivational methods (Black \& Margulies, 1989; Schwochau \& Delaney, 1997; Neubert \& Cady, 2001; Ketokivi \& Castaner, 2004) to ensure employees are motivated to deal with problems that arise without delay (Gill, 1996; McHugh, 1997; Clayton \& Gregory, 2000; Lewis et al., 2006).

\subsection{Explore Importance of the Problem}

Despite Lewin's (1943) pronouncement about the practicality of a good theory, if managers and academics think about change and employee involvement differently, even if an underlying theory is correct, then managers might not use it. To see how wide the gap might be, we begin with a brief overview of significant portions of the academic work on organization change and employee involvement. Then, we present the results of a single case study designed to learn how at least some managers think about introducing change. One caveat before we begin - - we are academics, consequently our understanding of how managers think about change was developed from the perspective of prior academic research.

\subsection{Describe Relevant Scholarship}

Research stressing the importance of gaining employee involvement in order to implement change has a long history. Existent research on involvement has appeared under a variety of labels, including participation and empowerment. 


\subsubsection{Ideological Entailments}

Gaining precise understanding of these terms is complicated by ideological commitments of various users. Some scholars, especially those with a more Marxist bent, find certain terms, particularly empowerment, to be useful tools for promoting their emancipatory agenda.

Consider Edwards and Collinson's (2002) observation that "empowerment was used originally by social movement and feminist writers" (p. 273). To some, the term empowerment connotes rather radical transformation of power relationships at work. For others, it represents "an effort to generate disciplined autonomy within a clearly understood set of expectations and priorities" (p. 274). It is little wonder that Styhre (2001) feared the term risks being turned into rhetoric with an ambiguous referent.

Other terms, such as participation, seem to have less extreme end points, but even there we see that sometimes writers link it to somewhat extreme change such as a democratic workplace. For example, some years ago Slater and Bennis (1964) stimulated by social science of the times that advanced human resources management to replace Taylorism, wrote that "democracy is inevitable." While this phrase could be interpreted as a major challenge to the capitalist system of the times, many champions of the human resources approach had no such radical agenda in mind. Nevertheless, as one studies the matter of worker involvement one must be aware that, in some writings, a term has radical transformation entailments and, in other writings, it has only pragmatic, managerialist ones. While anything approaching a full nuanced discussion of this matter is outside the scope of this paper, it is necessary to recognize the distinction. We will sometimes classify comments according to the degree of transformation they appear to imply. We will use the terms transformational vs. pragmatic to refer to the distinction.

\subsubsection{History of Academic Interest in Employee Involvement}

Much of the interest in topics such as participative management is grounded in the 1947 work of Kurt Lewin (Maynard et al., 2012). Some of Lewin's most well-known inquiry dealt with the use of participation to reduce resistance to change at the Harwood Manufacturing Corporation, where participation entailed involving workers in small discussion groups. The results were published in the now-famous paper by Coch and French (1948). This lineage apparently led many academics to view group discussions as the major step in implementing participative management. Even though one of the co-authors, Coch, was a personnel manager, this study gave us little insight about how the managers in general conceptualized employee involvement.

The emphasis on groups was evident in a second early stream of research, the contingency theory of leadership advanced by Vroom \& Yetton (1973). Vroom and Yetton proposed a normative theory to guide leaders choices concerning the degree to which groups should be involved in decisions. As with the Lewin and Coch \& French works, this research did not investigate how the managers viewed the involvement process.

Since this early research that was the foundation for interest in employee involvement, more recent work has increased our understanding of employee involvement in change efforts. Much of this work concerned communication.

\subsubsection{Importance of Communication in Empowerment and Organization Change}

The value of employee involvement for improving communication has been widely recognized. Lundberg's (1990) theoretical work explained how different types of communication can aid organization change. Further, Klein (1996) provided evidence concerning the way the communication process can help employees. He found that: 1) feedback and adjustments, 2) strategies that encourage disclosure of problems, and 3) discussion of solutions through intensive face-to-face communication between management and employees, was helpful.

In a similar vein, Gill (1996) observed that recent company history, trust factors, and communication methods could introduce barriers to communication in a change process. Introduction of a communication exercise prior to implementing a change contributed to success in implementing the change. Similarly, Tierny (1999) found that the quality of supervisor/employee relationships affected the degree to which an organization's climate was conducive to change.

Conger and Kanungo (1988) following study of the relationship of communication and empowerment, suggested organization change can lead to employees feeling powerless. To ensure that change does not fail, they advised managers to empower employees. Successful empowerment practices would provide information to employees about their self-efficiency. In related work, Holman (2000) advised managers to be clear about the purpose of the change and communicate with everyone early and often so that the change might become an ongoing conversation between everyone involved. 
Miles (2001) argued that to aid corporate change, managers should make all employees in high-engagement cascades that would generate understanding, dialogue, feedback, and accountability.

\subsubsection{Overview of History of Empowerment, Participation and Involvement in a Successful Change Effort}

The longstanding interest in employee involvement and change has produced a rather strong consensus in the academic literature that high levels of employee participation, involvement, empowerment, etc. can contribute to successful change.

However, it appears to us that there is a significant omission in this stream of research. Little study of how practicing managers view employee involvement in change has been done. This omission is particularly troublesome given the wide variety of labels academics have used to refer to employee involvement. Still, some of the more recent inquiry has provided some clues about the managers' views.

\subsubsection{Managers' Conceptualizations of Employee Involvement}

Although we know of no research, except for the study we report here, that has dealt directly with how managers view the role of employee involvement, several scholars have provided some clues. First, consistent with research discussed above, communication is a central concern. Second, practicing managers may not perceive terms that academics use to refer to employee involvement, particularly empowerment, as applicable. Third, managers at different levels may view employee involvement differently.

\subsubsection{Employee Involvement, Communication, and Change}

Two studies, one by Schweiger and DeNisi (1991) and one by Huy (2002), are instructive regarding communication.

In their study of mergers, Schweiger and DeNisi (1991) suggested that changes, such as mergers, may generate considerable anxiety that can have dysfunctional consequences. One way managers may deal with the problematic emotions is through communication. From their study of two plants engaged in mergers, they concluded that communication, in the form of realistic job preview, can help reduce uncertainty and help to stabilize the situation. Interestingly, they suggested that symbolic value of the communication showing that management cares, may be as important as actual content. The major significance of their findings for the present paper becomes evident in light of Huys' (2002) work.

Using the concept of bounded emotionality, Huy suggested that during radical change middle managers maintained operational continuity by encouraging employees to express a wide range of emotions. During changes, middle managers sought to lower unpleasant/low-activation feelings of disappointment and fatigue by sharing the feelings among themselves. Taken together with Schwieger and DeNisi's study, Huys' work leads us to speculate that some managers may find employee involvement to be helpful in managing subordinates' emotions during change.

\subsubsection{Managers May Not Perceive Concept of Empowerment as Applicable}

In addition to this speculative inference, Edwards and Collinson's (2002) work provided some more direct information about managers' conceptions of employee involvement efforts. They treated employee involvement under the heading of empowerment. Their findings supported Hales' (2000) analysis that the empowerment concept was elastic. Managers had difficulty defining the term, but whatever it was it was difficult to implement and the term was ...not a word used at local level (p. 287). Managers viewed the idea of empowerment as inapplicable because it meant giving workers a wide range of freedom.

"Managers were much happier with terms such as involvement and participation" (p. 288). They concluded that, in practice, managements "rarely attempt the far-reaching transformations that the langue of empowerment" (p. 293) suggests. Further, they noted that their findings were consistent with Hales' (2000) idea that junior-level managers have a pragmatic and context-dependent interpretation of empowerment.

\subsubsection{Managers' Conceptions of Empowerment Vary by Level}

Based on several case studies conducted in the UK, Hales (2000) concluded that junior-level managers interpreted empowerment differently than did senior managers. Hales speculated that for some senior managers empowerment provides a set of ideas that imply the need for junior managers has decreased. Junior-level managers are faced with changes that mean they can no longer claim exclusive responsibility for a liquid labor process. Terms like trainer/coach, advisor, troubleshooter, and information resources describe their roles. The language of empowerment is flexible enough to cover these roles and it is elastic enough to cover interpretations of the senior managers as well. In short, the word means different things to managers at different levels. 


\subsubsection{Overview of the Literature on Employee Involvement and Change}

Several important themes emerge from this study of literature on employee involvement and change. There is good reason to believe that some sort of employee involvement can often enhance change efforts. A likely reason for such improvement is better communication. A wide variety of terms is used to refer to the idea of employee involvement. Individual managers may interpret the same term differently.

Little study of how managers conceptualize employee involvement has been done, but the available clues suggest that inquiry is needed. The study reported below was motivated by our desire to satisfy this need. We conducted a single inductive case study.

\section{Method}

\subsection{Setting and the Change}

The study was conducted in a Greek-speaking, medium-sized media organization that recently implemented a major change - - the Personal Development Program. The program was introduced because due to the convergence of the European Union markets, this Greek-speaking organization had to operate in a very competitive media environment.

The personnel development program was intended to reduce costs and increase both the quantity and the quality of the programs produced. It was one of several programs the organization had introduced aimed at improving personnel quality.

The program included the introduction of new technologies, accompanied by special personnel educational programs aiming to improve employee skills and knowledge related to the new technologies. It also provided specific organizational arrangements that management hoped would achieve employee involvement through which employees could influence and contribute toward organizational decisions and operations.

Gaining employee involvement via the implementation of the program was intended to ensure that the opinions of the employees were taken into account and that they influenced both the organizational decisions and work level operations. However, management did not want to make joint decisions with employees. They only aimed for employees to have an input in the decisions the managers made.

To achieve the union's agreement and ensure all employees were thoroughly informed about the program, the Board held meetings with the employee trade union to explain its aims and how it was expected to operate. Besides the information and explanations received by their union, employees could also communicate with the management staff of their department for any further clarifications or questions focusing on specific departmental matters.

The program also included training. During the second three months of the program all organizational staff went through some Internet training conducted by external specialists in order to ensure they understood and were able to utilize the new facilities at work. By the middle of the year all new facilities were in place and all staff members were trained to use them.

\subsection{Research Design}

The single case study is used here inductively, in a manner consistent with Eisenhardt's (1989) recommendations for "building theory from case study research" According to Eisenhardt, "the case study is a research strategy which focuses on understanding the dynamics present within single settings where the evidence may be only qualitative". Case study research can be used to accomplish various aims including this paper's aim to generate theory from case study evidence (Gersick, 1988; Harris \& Sutton, 1986).

The authors collected data primarily through 22 in-depth interviews (lasting 1.5 to 2 hours) conducted over a period of five months with the departmental manager of the technical department and the departmental manager, the middle managers and the working unit leaders of the three departmental areas of the radio and music department (Talk Area First Radio, Music Area First Radio, Third Radio).

Two sets of interviews were conducted: 1) an initial interview with the manager of the technical department, and 2) semi-structured interviews with the seven managers of the radio and music department. Immediately after the interview, facts and impressions were cross-checked. Several rules were followed. First, the 24-hour rule required that detailed interview notes be completed within one day of the interview. Second, at the time of the interview, all data, regardless of apparent importance were included. In addition, secondary sources were consulted. Data were collected from internal documents, including the organization's annual summary and the annual published radio and music departmental review. 
Initial interviews centered on departments' operations and structures and on the implementation of the personnel development program. The second and third set of interviews were more structured and focused on specific organizational arrangements management provided employees with to achieve their involvement. 11 matters were discussed in total (See Appendix).

After the initial interview with the manager of the technical department, semi-structured interviews with all managers of the radio and music department were conducted.

In addition, questions were directed at obtaining factual accounts of what informants did or observed others doing.

\subsection{Data Analysis}

The search for consistent perspectives was assisted by selecting pairs of managers (middle managers and working unit leaders) within each of the three different departmental areas of the radio and music department, and listing similarities and differences between each pair.

Managers' thoughts about the change were classified under four general headings: 1) Perceptions of Organizational Arrangements Necessary to Gain Employee Involvement, 2) Empowerment Practices, 3) Motivation, and 4) Disclosure and Solution of Problems.

\section{Results}

\subsection{Initial Interviews}

In the initial interviews about the personnel development program, managers reported that, early on, the Board organized several meetings to inform management staff of all departments about the program and its aims. These meetings were accompanied by special training programs, aiming to contribute towards the improvement of employee skills and knowledge.

To aid introduction of new technologies, such as online facilities, the Board employed external Internet specialists to monitor, in association with all departmental management staff, the implementation of the necessary online facilities in all the organizational departments.

\subsection{Managers'Perceptions of the Organizational Arrangements Necessary to Achieve Employee Involvement}

Managers commented extensively on how to gain the support of employees, their unions, and of managers at different levels before the change and to retain that support after the implementation of employee involvement by encouraging and enabling employees to get involved in the decision-making process. Their ideas are presented in Table 1.

Managers emphasized communicating with employees through the union. The departmental manager's opinion was that "it was vital for the Board to explain to the employee's union the way the program would operate and its effects on the employees in order to gain their members support towards the implementation of the new process." The Talk Area middle manager believed that it:

...was important for management to achieve the support of the employee trade union because that was the only way to ensure all employees supported the new process at work. Otherwise, even if the majority agreed to support, the minority who disagreed would not work towards achieving its goals and this would affect its implementation negatively. The minority in this case could only be convinced by their trade union committee.

To sustain employee support and commitment, the managers noted that after the program implementation often they needed to explain that management aimed to achieve employee involvement. The middle manager of the Third Radio station explained that "Management needed to discuss and resolve any matters with the employee trade union even after the implementation of employee involvement to ensure continuous support." For example, in the Music Area the working unit leader said, it "was important to achieve because employees were suspicious and worried that by implementing employee involvement management might aim to increase both their control over employee jobs and the employees' workload." The Music Area middle manager's opinion was that explanations, illustrations and clarifications helped management reduce employee suspicions that management might not apply in reality what they agreed to apply in theory, and gain employee support and commitment towards the new process of employee involvement as a result. 
Table 1. Organizational Support

\begin{tabular}{|c|c|c|c|c|c|c|c|}
\hline $\begin{array}{l}\text { Organizational } \\
\text { arrangements }\end{array}$ & DM & $\begin{array}{l}\text { MM Talk } \\
\text { Area }\end{array}$ & $\begin{array}{l}\text { WUL Talk } \\
\text { Area }\end{array}$ & $\begin{array}{l}\text { MM Third Radio } \\
\text { Station }\end{array}$ & $\begin{array}{l}\text { WUL Third } \\
\text { Radio Station }\end{array}$ & MM Music Area & $\begin{array}{l}\text { WUL Music } \\
\text { Area }\end{array}$ \\
\hline $\begin{array}{l}\text { Gaining the } \\
\text { support of } \\
\text { employees and } \\
\text { their unions }\end{array}$ & $\begin{array}{l}\text { "Unions had a } \\
\text { major effect } \\
\text { over their } \\
\text { member's } \\
\text { opinion" }\end{array}$ & $\begin{array}{l}\text { "Employees } \\
\text { could only be } \\
\text { convinced by } \\
\text { their trade } \\
\text { union } \\
\text { committee" }\end{array}$ & & $\begin{array}{l}\text { "Management } \\
\text { needed to discuss } \\
\text { and resolve any } \\
\text { matters with the } \\
\text { employee trade } \\
\text { union even after } \\
\text { the } \\
\text { implementation of } \\
\text { employee } \\
\text { involvement" }\end{array}$ & $\begin{array}{l}\text { "It was } \\
\text { important for } \\
\text { management to } \\
\text { achieve the } \\
\text { support of the } \\
\text { employee trade } \\
\text { union" }\end{array}$ & $\begin{array}{l}\text { "Explanations, } \\
\text { illustrations and } \\
\text { clarifications help } \\
\text { management } \\
\text { reduce employee } \\
\text { suspicions about } \\
\text { their } \\
\text { involvement" }\end{array}$ & \\
\hline
\end{tabular}

\begin{tabular}{|c|c|c|c|}
\hline $\begin{array}{l}\text { Gaining the } \\
\text { support of } \\
\text { managers at } \\
\text { different levels }\end{array}$ & $\begin{array}{l}\text { "It was } \\
\text { important all } \\
\text { departmental } \\
\text { units could } \\
\text { implement } \\
\text { employee } \\
\text { involvement in } \\
\text { coordination" }\end{array}$ & $\begin{array}{l}\text { "WULS have } \\
\text { to ensure the } \\
\text { change is } \\
\text { implemented in } \\
\text { a coordinated } \\
\text { manner" }\end{array}$ & $\begin{array}{l}\text { "Managers } \\
\text { had to meet } \\
\text { regularly to } \\
\text { discuss } \\
\text { problems, } \\
\text { difficulties } \\
\text { and } \\
\text { successes } \\
\text { they } \\
\text { achieved" }\end{array}$ \\
\hline
\end{tabular}

The managers also believed that before the personnel development program was implemented the Board needed to discuss, explain the aims of employee involvement to the managers of the radio and music department, and gain their support. The departmental manager's said that "it was important to ensure all departmental units could implement employee involvement in coordination to avoid the risk that the departmental effort was impeded at any stage." The working unit leader of the Talk Area explained that "the job of the working unit leaders was important because they had the main managerial responsibility to implement employee involvement within their units." Consequently, they had to ensure the change was implemented in a coordinated way so that it ran smoothly in all units, and the departmental effort could not be obstructed. Due to the fact that all departmental units were interconnected problems spread and affected the implementation negatively.

In addition, the managers of the Music Area thought that when the implementation was assigned to working unit leaders, they had to arrange regular meetings to discuss problems, difficulties, and successes in order to find solutions to any problems and to sustain coordination in their efforts. When solutions could not be found, management staff meetings should be organized "so that the rest of the department's management staff could take part and offer their assistance."

In short, the managers thought that gaining the support of employees, their unions, and of managers at different levels, would encourage and enable employees to get involved in the decision making process. Two noteworthy themes from Table 1 are the emphasis managers placed on the role of the union in communication with the employees and the tone that emphasized "explaining" and "convincing."

\subsection{Employee Empowerment}

\subsubsection{Employee Development and Operational Freedom}

Table 2 reveals that managers thought that providing employees with both internal and external training (employee development) and promoting operational freedom (employee job autonomy and decision making authority) encourages and enables employees to get involved in the decision making process.

Some such as the managers of the Talk area observed that employees could get involved because training boosted and updated their professional knowledge and accomplished their development. At the Third Radio station, the working unit leader believed that management needed to organize training sessions and also give employees time after the end of the sessions to raise and clarify any outstanding personal matters. This was considered major because 
according to the working unit leader by doing so management helped employees improve their individual level of competence and made them feel that they operated in a context in which they were supported to get involved.

Regarding the provision of operational freedom, the departmental manager thought that employees who are "given control of their jobs in order to appreciate the job related matters and feel responsible to get involved in the decision making process." In addition, if they were given control and authority to consider matters in their areas, they would feel it was important to express their thoughts.

In the Talk Area, the middle manager's opinion was that "management had to ensure that all employees were given job autonomy and decision making authority in order to continue operating as a group, arguing that if this was not the case some employees might impose their authority and dissociate the rest of the group from the general management effort for employee involvement." The Talk Area working unit leader added that “...when employees were given job autonomy and decision making authority they did not feel restricted, appreciate all job-related matters and thus got involved and had an input towards the final management decisions made, noting that in the case of a media organization job autonomy could not exceed certain limits imposed by the media guidelines."

Managers in the Music Area suggested that "operational freedom was important for their area's employees because this way they did not feel restricted and could thus be creative. To be creative, they believed employees had to get involved in the making of decisions relating to the production of new, advanced and of high quality music related activities."

The managers appeared to think that empowerment practices like employee development and operational freedom were linked to the arrangements management needed to provide employees so as to encourage and enable them to get involved in the decision making process. These managers seemed to emphasize training and believe if employees were trained appropriately, allowing them high levels of discretion in their work would yield positive outcomes.

Table 2. Empowerment Practices

\begin{tabular}{|c|c|c|c|c|c|c|c|}
\hline $\begin{array}{l}\text { Empowerment } \\
\text { Practices }\end{array}$ & DM & $\begin{array}{l}\text { MM Talk } \\
\text { Area }\end{array}$ & $\begin{array}{l}\text { WUL Talk } \\
\text { Area }\end{array}$ & $\begin{array}{l}\text { MM Third } \\
\text { Radio Station }\end{array}$ & $\begin{array}{l}\text { WUL } \\
\text { Third } \\
\text { Radio } \\
\text { Station }\end{array}$ & $\begin{array}{l}\text { MM Music } \\
\text { Area }\end{array}$ & WUL Music Area \\
\hline $\begin{array}{l}\text { Employee } \\
\text { Development }\end{array}$ & $\begin{array}{l}\text { "All units } \\
\text { provide both } \\
\text { internal and } \\
\text { external training } \\
\text { for all } \\
\text { employees to } \\
\text { accomplish } \\
\text { their } \\
\text { development" }\end{array}$ & & $\begin{array}{l}\text { "Training } \\
\text { boosts and } \\
\text { updates the } \\
\text { employees' } \\
\text { professional } \\
\text { knowledge" }\end{array}$ & & $\begin{array}{l}\text { "Should } \\
\text { also give } \\
\text { employees } \\
\text { time after } \\
\text { the end of } \\
\text { the training } \\
\text { sessions to } \\
\text { clarify } \\
\text { outstanding } \\
\text { personal } \\
\text { matters" }\end{array}$ & & \\
\hline $\begin{array}{l}\text { Operational } \\
\text { Freedom }\end{array}$ & $\begin{array}{l}\text { "Employees are } \\
\text { given both } \\
\text { control of their } \\
\text { jobs and } \\
\text { authority to } \\
\text { consider their } \\
\text { area's matters" }\end{array}$ & $\begin{array}{l}\text { "All } \\
\text { employees } \\
\text { must be given } \\
\text { job autonomy } \\
\text { and decision } \\
\text { making } \\
\text { authority" }\end{array}$ & $\begin{array}{l}\text { "Can not } \\
\text { exceed } \\
\text { certain limits } \\
\text { imposed by } \\
\text { the media } \\
\text { guidelines" }\end{array}$ & $\begin{array}{l}\text { "Employees } \\
\text { consider } \\
\text { themselves as } \\
\text { being part of } \\
\text { management" }\end{array}$ & & & $\begin{array}{l}\text { "Employees do not } \\
\text { feel restricted and } \\
\text { can be creative" }\end{array}$ \\
\hline
\end{tabular}

\subsection{Employee Motivation}

From Table 3 we can see that the managers thought that ensuring that employee involvement leads to valued outcomes was important and that managers had a role in motivating employees to get involved in the decision making process. According to the managers this could be done in two ways.

First, management could motivate employees through providing both monetary and job satisfaction by offering job promotions, highlighting and praising the employees who got involved, and distributing a part of the organizational benefit resulting from their involvement back to them. The managers explained that in order to motivate employees "job promotions could be offered to employees who got involved and had an input about the goals of their area. Management could also make arrangements for those employees to attend related workshops and conferences overseas and organized staff meetings to praise them in front of their colleagues, and stressed the positive consequences of their involvement on their individual jobs." 
Second, the managers believed that motivation could also be achieved by ensuring that employees could see that their involvement affected the final decisions management made. However, as with respect to organization support discussed above, their tone emphasized explaining and convincing. The departmental manager explained that "the final management decisions made should be communicated and explained to employees soon after they were made." The Third Radio Station middle manager noted that "management needed not only to communicate to employees the final management decision made as a result of the discussions with them, but also explain to employees how their involvement affected those management decisions." The Talk Area working unit leader added that "this should be done soon after decisions were made." According to the two managers both issues were major for two reasons. Firstly because by doing so employees could clearly see that their opinions were taken into account and influenced the management decisions made, and secondly because any delay in providing explanations would make it difficult for employees to remember all matters and thus see clearly how they affected a past decision.

The managers thus thought that ensuring employee involvement leads to valued outcomes management motivates employees to get involved in the decision making process in a similar manner it motivates employees when aiming to achieve and manage an organizational change.

\subsection{Disclosure and Solution of Problems}

From Table 4 we can see that managers thought that by ensuring the disclosure and subsequent solution of employee problems without delay, management could encourage and enables employees to get involved in the decision making process.

For example the Talk Area middle manager's opinion was that "by systematically and regularly promoting" management-employee dialogue and two way discussions management encouraged employees to disclose problems, misunderstandings and conflicting views in relation to employee involvement. As a result management could correct deficiencies and provide explanations and clarifications enabling employees to get involved in the decision making process. In addition, the Third Radio middle manager believed that once management discovered employee concerns and problems managers would need to consider possible solutions together with employees. This was important because this way management would take into account employee suggestions and achieve employee acceptance and satisfaction as a result.

In the Talk Area the working unit leader expressed the view that "the managers had to meet and discuss with employees either in scheduled meetings or at their workplace in order to become aware of all their concerns and consider possible ways to overcome them." The Music Area middle manager noted that "employees needed to have the opportunity to present their areas of concern regularly so that they could be considered by management as soon as possible. Otherwise employees became easily and quickly disappointed, feeling unable to get involved."

In sum, the managers thought that by ensuring the disclosure and subsequent solution of employee problems without delay, management enables and encourages employees to get involved in the decision making process in a similar manner it encourages and enables employees to face any problems arising in the case of an organizational change.

Table 3. Motivation

\begin{tabular}{|c|c|c|c|c|c|c|c|}
\hline $\begin{array}{l}\text { Organizational } \\
\text { arrangements }\end{array}$ & DM & $\begin{array}{l}\text { MM Talk } \\
\text { Area }\end{array}$ & $\begin{array}{l}\text { WUL Talk } \\
\text { Area }\end{array}$ & $\begin{array}{l}\text { MM Third } \\
\text { Radio Station }\end{array}$ & $\begin{array}{l}\text { WUL Third } \\
\text { Radio Station }\end{array}$ & $\begin{array}{l}\text { MM } \\
\text { Music } \\
\text { Area }\end{array}$ & $\begin{array}{l}\text { WUL Music } \\
\text { Area }\end{array}$ \\
\hline $\begin{array}{l}\text { Employee } \\
\text { motivation }\end{array}$ & $\begin{array}{l}\text { "The final } \\
\text { management } \\
\text { decisions made } \\
\text { are } \\
\text { communicated } \\
\text { and explained to } \\
\text { employees" }\end{array}$ & & $\begin{array}{l}\text { "Communicating } \\
\text { and explaining } \\
\text { management } \\
\text { decisions to } \\
\text { employees must } \\
\text { be done soon } \\
\text { after decisions } \\
\text { are made" }\end{array}$ & $\begin{array}{l}\text { "Management } \\
\text { must also } \\
\text { explain to } \\
\text { employees how } \\
\text { their } \\
\text { involvement had } \\
\text { an influence on } \\
\text { the management } \\
\text { decisions" }\end{array}$ & & & $\begin{array}{l}\text { "Job } \\
\text { promotions, } \\
\text { attendance of } \\
\text { music related } \\
\text { workshops } \\
\text { overseas and } \\
\text { also praising } \\
\text { in front of } \\
\text { their } \\
\text { colleagues" }\end{array}$ \\
\hline
\end{tabular}


Table 4. Disclosure And Solution Of Problems

\begin{tabular}{|c|c|c|c|c|c|c|}
\hline $\begin{array}{l}\text { Organizational } \\
\text { arrangements }\end{array}$ & $\begin{array}{l}\text { MM Talk } \\
\text { Area }\end{array}$ & WUL Talk Area & $\begin{array}{l}\text { MM } \\
\text { Third } \\
\text { Radio } \\
\text { Station }\end{array}$ & $\begin{array}{l}\text { WUL Third } \\
\text { Radio Station }\end{array}$ & MM Music Area & $\begin{array}{l}\text { WUL } \\
\text { Music } \\
\text { Area }\end{array}$ \\
\hline $\begin{array}{l}\text { Management- } \\
\text { employee } \\
\text { dialogue, two } \\
\text { way } \\
\text { discussions }\end{array}$ & $\begin{array}{l}\text { "This way } \\
\text { employees } \\
\text { are } \\
\text { encouraged } \\
\text { to disclose } \\
\text { problems } \\
\text { and } \\
\text { management } \\
\text { can correct } \\
\text { deficiencies" }\end{array}$ & $\begin{array}{l}\text { "Managers have to meet } \\
\text { and discuss regularly } \\
\text { with employees to } \\
\text { become aware of their } \\
\text { concerns and consider } \\
\text { possible ways to } \\
\text { overcome them" }\end{array}$ & & $\begin{array}{l}\text { "Management } \\
\text { has to consider } \\
\text { possible } \\
\text { solutions } \\
\text { together with } \\
\text { employees" }\end{array}$ & $\begin{array}{l}\text { "If employees cannot } \\
\text { present their areas of } \\
\text { concern regularly they } \\
\text { become easily and quickly } \\
\text { disappointed" }\end{array}$ & \\
\hline
\end{tabular}

\section{Discussion}

A major purpose of this paper was to learn how closely the ways managers seeking to introduce change think about gaining employee involvement and compare them to the academic theories mentioned earlier on.

When the various comments are viewed together, an interesting pattern can be seen.

First, the managers shared the academic literature's emphasis on the importance of employee involvement for accomplishing organization objectives. Interestingly, one of these objectives was promptly achieving objectives. The managers thought that by ensuring the disclosure and subsequent solution of employee problems without delay management encourages and enables them to get involved in the decision making process.

Importantly, adoption of the managers' perspective helped us to see some interesting nuances in how managers thought about how to gain this involvement. Two things were noteworthy. First, their idea of involvement placed much more emphasis on explaining and convincing than is evident in typical academic treatments where a tone of mutual influence seems to be more evident. Second, it was the proactive stance they felt they needed to take. In particular, they saw working with and through the union as highly important. In addition, there were a number of things they believed they needed to do. Consistent with much of the academic literature, many of these were quite pragmatic. Communication was clearly the most salient. Other pragmatic-centered matters included: providing training, motivating involvement, providing information about the process and results, and the importance of immediately attending to problems. It is notable that much, but not all, the concern with communication called for explaining. Whereas much of the academic literature also stresses communication, our results point to the need to recognize the somewhat obvious idea that not all calls for communication are necessarily calls for the same thing. Communication focused on explaining and convincing is not likely to be a call for the dialogue many academics seem to have in mind.

Of course, these specific activities, especially the emphasis placed on using the union to communicate, may well be idiosyncratic to this particular setting and thus cannot be generalized, at least at this point.

On the other hand, what may be generalized and serve as a stimulus for future research is the finding that these managers thought of rather specific things that they needed to do, at least in this context, to gain the desired employee involvement. Thus, the results are a first step in addressing the lacuna in the academic literature we pointed to at the start.

While transmitting information seemed to be the major benefit of involvement, other, more abstract benefits, were also expected. A major one was gaining the support of both employees and managers.

Some managers believed that by gaining the support of employees, their unions, and of managers at different levels management encourages and enables employees to get involved in the decision making process. Further, they believed that management must gain the support and commitment of employees, their unions, and of managers before implementation and retain that support after the implementation of employee involvement. Among other things, they believed that to gain employee involvement, management needed to provide all necessary explanations, illustrations and clarifications before and after the implementation of employee involvement in order to reduce any suspicions that management may not apply in reality what they agreed to apply in theory.

In addition to these pragmatic interests, when the data were considered through an empowerment lens, some limited themes consistent with the emancipatory spirit appeared. For example, comments in Table 2 emphasized 
development and operational freedom. In addition, recall that some managers in the music area viewed the involvement as contributing to creativity.

This study also adds insights relating to the use of empowerment practices by management towards employees like the provision of employee development and operational freedom.

The managers saw the provision of employee training as especially important because employee development and training boosts and updates their professional knowledge and skills. In other words, management needs to give employees time after the end of the training sessions to raise and clarify any outstanding personal matters because this way employees improve their individual level of competence and feel that they operate in a context in which they are supported to get involved in the decision making process.

The managers also suggested that providing employees with operational freedom, job autonomy, and decision making authority, made them feel supported and encouraged to get involved. According to some of the managers interviewed, operational freedom is important to provide to employees also because by doing so management ensures employees do not feel restricted and can thus be creative during the decision making process. In addition, it is important for management to ensure that all employees are given operational freedom in order to continue operating as a group because otherwise some may impose their authority and disassociate from the rest of the general management effort for employee involvement.

The data also produced insights concerning the use of several motivational methods by management to achieve employee motivation.

The managers believed that management can motivate employees by ensuring that their involvement leads to valued outcomes that can be seen by them. This according to the managers can be done in monetary and/or job satisfaction terms, and by making the final management decisions known to employees. In other words, managers need to provide explanations to employees on how their suggestions affected the final management decision made. These explanations must be communicated to employees soon afterwards in order for them to see clearly that their opinions are taken into account and have an influence over the final management decisions. Any delay in providing explanations will make it difficult for employees to remember all matters and thus see clearly how they affected a past decision.

Recall that some previous research suggested that managers at different levels may view employee involvement differently. Our findings support this possibility. Recall that the designers of the personnel development program did not want joint decisions, but only to provide a mechanism for letting employees have input. Yet, as Table 3 revealed, some of the lower-level managers mentioned such things as giving employees control over their job and have employees consider themselves as part of management. Thus, our findings suggest it is unlikely that all managers view employee involvement in the same way. Future study should recognize this likelihood and investigate the difference.

It is important to recognize some limitations of this study. In interpreting these results, it must be recognized that the study dealt with one particular type of change in one setting and enclosed included only a few managers. Thus while the finding suggest the need for future research, they must be interpreted cautiously.

This paper addressed managers' conceptions of employee involvement in a rapidly-changing media environment. The results are derived from a single case and thus are, at best, suggestive. The study arose from concern that little was known about how managers view employee involvement. Although a case study of this sort cannot provide generalized results, it did yield some important insights into an underdeveloped topic. Specifically, the study of involvement (and the various headings related to it) can be advanced by study of how managers view it. Among other things, as might be expected, pragmatic matters are apt to be salient. Matters of information transmission and timely responses are likely to be central. Interestingly, whereas the academic literature frequently suggests participative methods are slow, the managers in this study viewed employee involvement as a means of prompt response. Moreover, consistent with some previous findings, it appears that managers at different levels viewed employee involvement differently.

Of special note is that while both managers and academics emphasize the same word - - communication - - as a benefit of employee involvement, they are not necessarily discussing the same thing. Study of how managers think about communication revealed what may be an important difference. Managers may be focusing on explaining and convincing. Academics may be more apt to concentrate on dialogue. Future inquiry into this subtle dissimilarity that might make all the difference would seem to be heading towards a good direction. 


\section{Appendix}

\section{List of Matters discussed during the Interviews}

Description of the Department

1.Operations and structure

2.Implementation of the Personnel Development Program

Provision of necessary organizational arrangements

3.Regularly express confidence to employees

4.Promote employee development by providing employees with training sessions to expand their professional learning and skills

5.Promote operational freedom by yielding job autonomy and decision making authority to employees

6.Ensure involvement leads to valued outcomes that can be seen by employees

7.Discuss and explain the goals of this effort to trade unions in order to gain their continuous support

8.Explain to employees why they are invited to get involved

9. Gain the support of all the managers of the department

10.Promote systematically and regularly management-employee dialogue and two way discussions

11.Motivate employees in both monetary and job-satisfaction terms.

\section{References}

Bandura, A. (1986). Social foundations of thought and action: A social cognitive view. Englewood Cliffs, NJ: Prentice-Hall.

Black, S., \& Margulies, N. (1989). An ideological perspective on participation: A case for integration. Journal of Organizational Change Management, 2(1), 13-35. http://dx.doi.org/10.1108/09534818910134068

Block, P. (1987). The empowered manager. San Francisco: Jossey -Bass.

Clayton, J., \& Gregory, W. J. (2000). Reflections on critical systems thinking and the management of change in rule-bound systems. Journal of Organizational Change Management, 13(2), 140-161. http://dx.doi.org/10.1108/09534810010321472

Cobb, A.T., Folger, R. \& Wooten, K. (1995). The role justice plays in organizational change, Public Administration Quarterly, 19(2), 135-152.

Coch, L., \& French, Jr, J. R. P. (1948). Overcoming resistance to change, Human Relations, 1, 512-532. http://dx.doi.org/10.1177/001872674800100408

Conger, J. A. (1986). Empowering leadership. Montreal: McGill University.

Conger, J. A., \& Kanungo, R. N. (1988). The empowerment process: integrating theory and practice, Academy of Management Review, 13 (3), 471-482. http://dx.doi.org/10.5465/AMR.1988.4306983

Delaney, J. T., \& Sockell, D. (1990). Employee involvement programs, unionization and organizational flexibility. Academy of Management Best Paper Proceedings, 264-269.

Detert, R. J., \& Burris, R. E. (2007). Leadership behavior and employee voice: Is the door really open? Academy of Management Journal, 50(4), 869-884. http://dx.doi.org/10.5465/AMJ.2007.26279183

Edwards, P., \& Collinson, M. (2002). Empowerment and managerial labor strategies: Pragmatism regained. Work and Occupations, 29(3), 272-299. http://dx.doi.org/10.1177/0730888402029003002

Eisenhardt, K. M. (1989). Building Theory from Case Study Research. Academy of Management Review, 14(4), 532-550. http://dx.doi.org/10.5465/AMR.1989.4308385

Gersick, C. (1988) Time and transition in work teams: Toward a new model of group development. Academy of Management Journal, 31(1), 9-41. http://dx.doi.org/10.2307/256496

Gill, J. (1996). Communication - Is it really that simple? An analysis of a communication exercise in a case study. Personnel Review, 25(5), 23-37. http://dx.doi.org/10.1108/00483489610130913

Hales, C. (2000). Management and empowerment programmes. Work, Employment and Society, 14(3), 501-519. http://dx.doi.org/10.1177/09500170022118545

Harris, S., \& Sutton, R. (1986). Functions of parting ceremonies in dying organizations. Academy of Management Journal, 29(1), 5-30. http://dx.doi.org/10.2307/255857

Holman, P. (2000). Culture Change, Executive Excellence, 17(7), 16. 
Huy, Q.N. (2002). Emotional balancing of organizational continuity and radical change: The contribution of middle managers. Administrative Science Quarterly, 47(1), 31-69. http://dx.doi.org/10.2307/3094890

Ketokivi, M., \& Castaner, X. (2004). Strategic planning as an integrating device. Administrative Science Quarterly, 49(3), 337-365.

Klein, S. M. (1996). A Management Communication Strategy for Change. Journal of Organizational Change Management, 9(2), 32-46. http://dx.doi.org/10.1108/09534819610113720

Lewin, K. (1943). Psychology and the process of group living. Journal of Social Psychology, 17, 113-131. http://dx.doi.org/10.1080/00224545.1943.9712269

Lewis, K.L., Schmisseur, M.A., Stephens, K.K., \& Weir, K. E. (2006). Advice on communicating during organizational change. Journal of Business Communication, 43(2), 113-137. http://dx.doi.org/10.1177/0021943605285355

Lundberg, C. C. (1990). Towards Mapping the Communication Targets of Organisational Change. Journal of Organizational Change Management, 3(3), 6-14. http://dx.doi.org/10.1108/09534819010001540

Maynard, M. T., Mathieu, J. E., Gilson, L. L., O’Boyle Jr., E. H. \& Cigularov, K. P. (2012). Drivers and outcomes of team psychological empowerment: A meta-analytic review and model test. Organizational Psychology Review, 3(2), 101-137. http://dx.doi.org/10.1177/2041386612456868

McHugh, M. (1997). The stress factor: another item for the change management agenda. Journal of Organizational Change Management, 10(4), 345-362. http://dx.doi.org/10.1108/09534819710175866

Miles, R. H. (2001). Accelerating Corporate Transformations by Rapidly Engaging All Employees. Organizational Dynamics, 29(4), 313-322. http://dx.doi.org/10.1016/S0090-2616(01)00036-5

Morgan, D.E., \& Zeffane, R. (2003). Employee involvement, organizational change and trust in management. International Journal of Human Resource Management, 14(1), 55-75. http://dx.doi.org/10.1080/09585190210158510

Neubert, M. J., \& Cady, S. H. (2001). Program commitment: A multi-study longitudinal field investigation of its $\begin{array}{llll}\text { impact and antecedents. Personnel } & \text { Psychology, }\end{array}$ http://dx.doi.org/10.1111/j.1744-6570.2001.tb00098.x

Nord, W. R., Rosenblatt, Z., \& Rogers, K. (1993). Toward a political framework for flexible management of decline. Organization Science, 4(1), 76-91. http://dx.doi.org/10.1287/orsc.4.1.76

Rusaw, C. A. (2000). Uncovering training resistance: A critical theory perspective. Journal of Organizational Change Management, 13(3), 249-263. http://dx.doi.org/10.1108/09534810010330896

Schweiger, D. M., \& DeNisi, A. S. (1991). Communication with employees following a merger: A longitudinal field experiment. Academy of Management Journal, 34(1), 110-135. http://dx.doi.org/10.2307/256304

Schwochau, S., \& Delaney, J. (1997). Employee participation and assessments of support for organizational policy changes. Journal of Labor Research, 18(3), 379-402. http://dx.doi.org/10.1007/s12122-997-1046-z

Slater, P. E., \& Bennis, W.G. (1964). Democracy is inevitable. Harvard Business Review, 42(2), 51-59.

Styhre, A. (2001). Kaizen, ethics, and care of the operations: Management after empowerment. Journal of Management Studies, 38(6), 795-810. http://dx.doi.org/10.1111/1467-6486.00259

Tangirala, S., \& Ramanujam, R. (2008). Exploring nonlinearity in employee voice: The effect of personal control and organizational identification. Academy of Management Journal, 51(6), 1189-1203. http://dx.doi.org/10.5465/AMJ.2008.35732719

Tesluk, P. E., Vance, R. J., \& Mathieu, J. E. (1999). Examining employee involvement in the context of participative work environments. Group and Organization Management, 24(3), 271-300. http://dx.doi.org/10.1177/1059601199243003

Tierney, P. (1999). Work relations as a precursor to a psychological climate for change. Journal of Organizational Change Management, 12(2), 120-135. http://dx.doi.org/10.1108/09534819910263668

Vroom, V. H. (1973). A new look at managerial decision making. Organizational Dynamics,1(4), 66-80. http://dx.doi.org/10.1016/S0090-2616(73)80024-5

Yin, R.K. (2003). Case study research: Design and methods. Thousand Oaks, CA: Sage.

Zhang, X., \& Bartol, M. K. (2010). Linking empowering leadership and employee creativity: The influence of psychological empowerment, intrinsic motivation and creative process engagement. Academy of Management Journal, 53(1), 107-128. http://dx.doi.org/10.5465/AMJ.2010.48037118 